\title{
Isolation and characterization of anti-inflammatory peptides derived from whey protein
}

\author{
Ye Ma, ${ }^{*}$ Jie Liu, $\dagger^{1}$ Haiming Shi, ${ }^{* 1}$ and Liangli (Lucy) Yuł \\ *Institute of Food and Nutraceutical Science, School of Agriculture and Biology, Shanghai Jiao Tong University, Shanghai 200240, China \\ †Beijing Advanced Innovation Center for Food Nutrition and Human Health, Beijing Technology \& Business University, Beijing 100048, China \\ ‡Department of Nutrition and Food Science, University of Maryland, College Park 20742
}

\begin{abstract}
The present study was conducted to isolate and characterize anti-inflammatory peptides from whey protein hydrolysates using alcalase. Nine subfractions were obtained after sequential purification by ultrafiltration, Sephadex G-25 gel (GE Healthcare, Uppsala, Sweden) filtration chromatography, and preparative HPLC. Among them, subfraction F4e showed the strongest

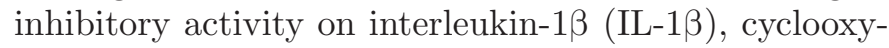
genase-2, and tumor necrosis factor- $\alpha$ (TNF- $\alpha$ ) mRNA expression in lipopolysaccharide-induced RAW 264.7 mouse macrophages. Eight peptides, including 2 new peptides-Asp-Tyr-Lys-Lys-Tyr (DYKKY) and AspGln-Trp-Leu (DQWL) - were identified from subfractions F4c and F4e, respectively, using ultra-high performance liquid chromatography-quadrupole-time-offlight mass spectrometry. Peptide DQWL showed the strongest inhibitory ability on IL-1 $\beta$, cyclooxygenase- 2 , and TNF- $\alpha$ mRNA expression and production of IL-1 $\beta$ and TNF- $\alpha$ proteins at concentrations of 10 and 100 $\mu \mathrm{g} / \mathrm{mL}$, respectively. Additionally, DQWL treatment significantly inhibited nuclear factor- $\kappa \mathrm{B}$ activation by suppressing nuclear translocation of nuclear factor- $\kappa \mathrm{B}$ p65 and blocking inhibitor $\kappa \mathrm{B}$ kinase phosphorylation and inhibitor $\mathrm{\kappa B}$ degradation together with p38 mitogen-activated protein kinase activation. Our study suggests that peptide DQWL has anti-inflammatory potential; further confirmation using an in vivo model is needed.
\end{abstract}

Key words: anti-inflammatory peptide, whey protein, purification, alcalase

\section{INTRODUCTION}

Inflammation is a common defensive reaction of human body upon harmful stimuli, such as physical

\footnotetext{
Received March 17, 2016.

Accepted June 4, 2016.

${ }^{1}$ Corresponding authors: liujiefantasy@163.com and hmshi@sjtu. edu.cn
}

trauma, chemical exposure, and bacterial or viral infections. However, low-level inflammation is considered to be highly associated with the initiation and progress of cardiovascular diseases (Kaperonis et al., 2006), cancers (Coussens and Werb, 2002), diabetes (Dandona et al., 2005), and Alzheimer's disease (Tuppo and Arias, 2005). Over the past decade, growing evidence has demonstrated the potential of dietary components in mitigating and even blockading the progression of inflammation (Giugliano et al., 2006; Pan et al., 2009).

Peptides are an important group of bioactive substances in functional foods, which can be generated by enzymatic hydrolysis, microbial fermentation, or gastrointestinal digestion of food protein. Bioactive peptides are usually composed of 3 to 20 AA residues and may contain different AA composition and sequence (Shahidi and Zhong, 2008). Recently, interest has been growing in developing anti-inflammatory peptides from food proteins for their health-promoting effects and desirable safety (Dyer et al., 2008; Chakrabarti et al., 2014; Kumar et al., 2015).

Whey protein constitutes approximately $20 \%$ of milk protein and is a natural by-product from cheese production. Whey protein is basically a mixture of globular protein, such as $\beta-\mathrm{LG}, \alpha-\mathrm{LA}$, immunoglobulin, and BSA. As a high-quality protein source (Sousa et al., 2012), whey protein could release a wide variety of bioactive peptides. However, a previous study on bioactive peptides originated from whey protein primarily focused on their antioxidative, antibacterial, immunomodulatory, as well as angiotensin-I converting enzyme (ACE)- and dipeptidyl peptidase-IVinhibitory activities (Madureira et al., 2010). Limited research exists on the anti-inflammatory property of whey-derived peptides. Recently, several reports have shown the potential anti-inflammatory activities of whey protein hydrolysates (WPH) in vivo (CarvalhoSilva et al., 2012; Tavares et al., 2013); however, these studies were all based on the WPH fractions and the chemical structures of the anti-inflammatory peptides remain unclear. Therefore, additional study is needed to purify the peptides with potential anti-inflammatory 
activities from WPH and to characterize their chemical structures, including AA compositions and sequences.

The purpose of the current study was to purify the potential anti-inflammatory peptides derived from WPH by alcalase, and characterize their AA sequences using ultra-high-performance liquid chromatographyquadrupole-time-of-flight mass spectrometry (UPLCQ-TOF-MS). Furthermore, the identified peptides were synthesized to evaluate their potential antiinflammatory activities in the LPS-stimulated RAW 264.7 mouse macrophage cells. Our study might promote the use of hydrolyzed peptides from whey protein as bioactive ingredients in functional foods.

\section{MATERIALS AND METHODS}

\section{Materials and Reagents}

Bovine whey protein isolates (protein content, approximately 70\%) was obtained from Murray Goulburn Co-Operative Co. Ltd. (Victoria, Australia) and stored at $-20^{\circ} \mathrm{C}$ until use. Alcalase 2.4L FG (EC 3.4.21.62) was purchased from Novozymes Corp. (Bagsvaerd, Denmark). Sephadex G-25 medium (50-150 $\mu \mathrm{m})$ was purchased from GE Healthcare (Uppsala, Sweden). Acetonitrile and trifluoroacetic acid (TFA), formic acid, and HPLC-grade solvents were obtained from Sigma-Aldrich (St. Louis, MO). RAW 264.7 macrophage cells were purchased from the Chinese Academy of Sciences (Shanghai, China). Lipopolysaccharide from Escherichia coli O111:B4 was obtained from Millipore (Bedford, MA). Dulbecco's modified Eagle's medium (DMEM) and 3-(4,5-dimethylthiazol-2-yl)-2,5-diphenyltetrazolium-bromide (MTT) were purchased from Life Technologies (New York, NY). TRIzol reagent was purchased from Invitrogen (Carlsbad, CA) and an IScript Advanced cDNA Synthesis kit was purchased from Bio-Rad (Hercules, CA). Antibodies against extracellular signal-regulated kinase (ERK1/2), p-ERK1/2, p-38, pp-38, c-Jun N-terminal kinase (JNK), p-JNK, phosphorylation $\kappa B$ kinase $(\mathbf{p}-\mathbf{I K K} \boldsymbol{\alpha} / \boldsymbol{\beta})$, nuclear factor- $\kappa \mathrm{B}(\mathbf{N F}-\kappa \mathbf{B}$ p65), inhibitor $\kappa \mathrm{B}(\mathbf{I} \kappa \mathbf{B} \boldsymbol{\alpha})$, and secondary antibody were purchased from Cell Signaling Technology (Beverly, MA). All reagents and chemicals were analytical or HPLC grade.

\section{Preparation of WPH}

Whey protein solution $(6 \%$, wt $/ \mathrm{vol})$ was denatured at $85^{\circ} \mathrm{C}$ for $10 \mathrm{~min}$ then the $\mathrm{pH}$ was adjusted to 8.0 . The sample was hydrolyzed at $55^{\circ} \mathrm{C}$ for $6 \mathrm{~h}$ using the $2.4 \mathrm{~L}$ alcalase with a substrate-to-enzyme ratio of $50: 3$ (wt/wt). The hydrolysis was terminated by heating the sample at $90^{\circ} \mathrm{C}$ for $10 \mathrm{~min}$ to inactivate the enzyme. The enzymatic hydrolysate was cooled to room temperature and subsequently centrifuged at $6,738 \times g$ for 20 min at $4^{\circ} \mathrm{C}$. The $\mathrm{pH}$ of the supernatant, referred to as WPH, was adjusted to 7.0, lyophilized, and stored at $-20^{\circ} \mathrm{C}$ for subsequent purification. A flowchart of purification of WPH was provided in Supplemental Figure S1 (http://dx.doi.org/10.3168/jds.2016-11186).

\section{UF}

The WPH was dissolved in water $(3 \%, \mathrm{wt} / \mathrm{vol})$ and fractionated by a Minimate tangential flow filtration system and capsules (Pall Life Science, Port Washington, NY). Fractionation was sequentially carried out using membranes with 5- and 1-kDa (polyether sulfone) cut-off values under pressure $(206.7 \mathrm{kPa})$. Three fractions corresponding to molecular weight (MW) below $1 \mathrm{kDa}$, between 1 and $5 \mathrm{kDa}$, and above $5 \mathrm{kDa}$ were prepared by repeating the UF 5 times with yields of 44,27 , and $29 \%$, respectively. The fractions were lyophilized and stored at $-20^{\circ} \mathrm{C}$ for the bioactivity determination. The fraction exhibiting the strongest bioactivity was collected for the subsequent purification.

\section{Purification of Whey Fraction for Anti-inflammatory Activity}

The anti-inflammatory fraction $(50 \mathrm{mg})$ was dissolved in $1 \mathrm{~mL}$ of deionized water and fractionated by gel filtration chromatography on a Sephadex G-25 column, and then eluted with deionized water at a flow rate of $0.5 \mathrm{~mL} / \mathrm{min}$. Elution was monitored by measuring the absorbance at $280 \mathrm{~nm}$ on a multimode reader (Tecan, Männedorf, Switzerland). After the bioactive effects were determined, the fractions with the significant activity were pooled and lyophilized for purification by preparative HPLC.

\section{Isolation of Bioactive Fraction by Preparative HPLC}

The fraction exhibiting the strongest bioactivity (10 $\mathrm{mg} / \mathrm{mL}, 1.5 \mathrm{~mL}$ ) was further separated using a preparative Waters HPLC system (Milford, MA), consisted of a 1525 binary HPLC pump, a manual injector and a 2489 $\mathrm{UV} /$ Visible detector. The separation was performed on a Waters Sunfire $\mathrm{C}_{18}$ OBD preparative column $(250 \times 19 \mathrm{~mm}$ i.d., $5 \mu \mathrm{m})$ with $8 \mathrm{~mL} / \mathrm{min}$ flow rate at $30^{\circ} \mathrm{C}$. The mobile phase consisted of a combination of A $(0.1 \%$ TFA in water, vol/vol) and $\mathrm{B}(0.1 \%$ TFA in acetonitrile, vol/vol). The linear gradient started from $5 \% \mathrm{~B}$, holding for $2 \mathrm{~min}$, increasing to $25 \% \mathrm{~B}$ at $60 \mathrm{~min}$ 
to $60 \% \mathrm{~B}$ at $62 \mathrm{~min}$, and held for $3 \mathrm{~min}$. The elution was monitored at $280 \mathrm{~nm}$ and 9 major fractions were collected. The corresponding fractions obtained from 3 repeated runs were collected to test their activities and identify the peptide composition.

\section{Cell Viability}

Cell viability was measured by MTT assay. RAW 264.7 cells were seeded in a 96-well plate with DMEM medium in the presence of fetal bovine serum $10 \%$ plus $1 \%$ of amphotericin $\mathrm{B}$, streptomycin, or penicillin at 7,500 cells /well and incubated for $24 \mathrm{~h}$. After discarding the old medium, the cells were incubated in the medium containing 10 and $100 \mu \mathrm{g} / \mathrm{mL}$ of whey peptides or synthetic peptides. After $24 \mathrm{~h}$ of incubation, the cells were treated with $20 \mu \mathrm{L}$ of MTT $(5 \mathrm{mg} / \mathrm{mL}$ ) for another $4 \mathrm{~h}$. The dark blue formazan crystals formed in intact cells were extracted in $150 \mu \mathrm{L}$ of DMSO and the absorbance at $565 \mathrm{~nm}$ was measured with a Tecan M200 PRO microplate reader. Cell viability (\%) was expressed as the optical density ratio of the treatment to control.

\section{Real-Time PCR Analysis}

RAW 264.7 mouse macrophage cells were cultured in DMEM supplemented with $10 \%$ fetal bovine serum, $1 \%$ of amphotericin B, streptomycin, or penicillin and maintained in a humidified incubator at $37^{\circ} \mathrm{C}$ with $5 \%$ $\mathrm{CO}_{2}$. The cells were cultured in 6 -well plates to reach a confluence of $80 \%$. Then they were treated with medium containing WPH for $48 \mathrm{~h}$ at an initial concentration of $100 \mu \mathrm{g} / \mathrm{mL}$. After pretreatment, LPS was added at a final concentration of $10 \mathrm{ng} / \mathrm{mL}$ for another $4 \mathrm{~h}$. After induction, culture medium was discarded and cells were lysed with Trizol to extract RNA and prepared for subsequent real-time PCR.

Total RNA was isolated from RAW 264.7 cells using the Trizol reagent, followed by the reverse transcription cDNA using an IScript Advanced cDNA Synthesis kit. Real-time PCR was carried out on an ABI 7900HT Fast Real-Time PCR System (Applied Biosystems, Carlsbad, CA) using AB Power SYBR Green PCR Master Mix. The PCR amplification of cDNA in our study was performed with the following primers: cyclooxygenase (COX)-2 (forward: 5'-GGGAGTCTGGAACATTGTGAA-3', reverse: 5'-GCACGTTGATTGTAGGTGGACTGT-3'); IL-1 $\beta$ (forward: 5'-GTTGACGGACCCCAAAAGAT-3', reverse: 5'-CCTCATCCTGGAAGGTCCAC- $3^{\prime}$ ); tumor necrosis factor (TNF)- $\alpha$ (forward: 5'-AGCCGATGGGTTGTACCTTGTCTA-3', reverse: 5'-TGAGATAGCAAATCGGCT-
GACGGT-3'); GAPDH (forward: 5'-CATCTTCTC AAAATTCGAGTGACAA-3', reverse: 5'-TGGGAGTAGACAAGGTACAACCC-3'). Amplification parameters used for PCR were $50^{\circ} \mathrm{C}$ for $2 \min , 95^{\circ} \mathrm{C}$ for 10 min, and 40 cycles of amplification at $95^{\circ} \mathrm{C}$ for $15 \mathrm{~s}$ and $60^{\circ} \mathrm{C}$ for $1 \mathrm{~min}$.

\section{UPLC-Q-TOF-MS Analysis}

The peptide profile of HPLC fractions showing antiinflammatory activity was obtained on Waters Xevo G2 Q-TOF mass spectrometer. The UPLC analysis was performed at $40^{\circ} \mathrm{C}$ using an Acquity UPLC CSH $\mathrm{C}_{18}$ column $(100 \times 2.1 \mathrm{~mm}$ i.d., $1.7 \mu \mathrm{m}, 130 \AA)$, with a 5 $\times 2.1 \mathrm{~mm}$ i.d. guard column of the same material (Waters). The elution gradient (eluent A, $0.1 \%$ formic acid in water; eluent B, $0.1 \%$ formic acid in acetonitrile) was used as follows: 0 to $2 \mathrm{~min}, 2 \% \mathrm{~B} ; 2$ to $60 \mathrm{~min}$, $15 \% \mathrm{~B} ; 60$ to $70 \mathrm{~min}, 60 \% \mathrm{~B} ; 70$ to $80 \mathrm{~min}, 60 \% \mathrm{~B} ; 80$ to $82 \mathrm{~min}, 2 \% \mathrm{~B}$; and 82 to $90 \mathrm{~min}, 2 \% \mathrm{~B}$. The flow rate was $0.3 \mathrm{~mL} / \mathrm{min}$ and the injection volume was 5 $\mu \mathrm{L}$. Mass data were obtained by an electrospray ionization in positive ion mode and was calibrated using the lock-mass function with leucine encephalin. Mass spectrometry conditions were capillary voltages of $2.5 \mathrm{kV}$; sampling cone voltages of $30.0 \mathrm{~V}$; source temperature $120^{\circ} \mathrm{C}$; desolvation temperature $450^{\circ} \mathrm{C}$; desolvation gas flow $600.0 \mathrm{~L} / \mathrm{h}$; cone gas flow $50.0 \mathrm{~L} / \mathrm{h}$; scan range of 50 to $1,200 \mathrm{~m} / z$; scan time of $0.3 \mathrm{~s}$; and interscan time of 0.02 s. Data were collected and analyzed with Waters MassLynx v4.1 and BiopharmaLynx 1.3.3 software (Waters Corporation, Milford, MA).

\section{Peptide Synthesis}

Eight peptides identified by UPLC-Q-TOF-MS/MS were synthesized by the solid phase procedure and purified by GL Biochem (Shanghai, China). The purity of the peptides was determined above $98 \%$ by HPLC and LC-MS analysis. Synthetic peptides were freeze-dried before use.

\section{ELISA}

RAW 264.7 cells were seeded in 12 -well plates (7.5 $\times 10^{4}$ cells $/ \mathrm{mL}$ ), and incubated for $24 \mathrm{~h}$. Then, the cells were treated with medium containing synthetic peptides for $24 \mathrm{~h}$ at initial concentrations of 10 and 100 $\mu \mathrm{g} / \mathrm{mL}$. After pretreatment, the cells were incubated in the presence of $10 \mathrm{ng} / \mathrm{mL}$ of LPS for $24 \mathrm{~h}$. Cellfree supernatants were collected for the determination of IL-1 $\beta$ and TNF- $\alpha$, with corresponding commercial mouse ELISA kits (eBioscience, San Diego, CA, and 
R\&D Systems, Minneapolis, MN) according to the manufacturer's instructions. The optical density of the microplate was read at $450 \mathrm{~nm}$. Protein contents were measured by BCA method (Pierce, Rockford, IL).

\section{Western Blotting}

For preparation of whole cell extracts, cells were harvested using a cell scraper and lysed with icecold RIPA buffer containing protease inhibit cocktail (Sigma Aldrich) and phosphatase inhibitors (Roche Diagnostics, Mannheim, Germany). The total cell lysates were then centrifuged at $10,000 \times g$ for $20 \mathrm{~min}$ at $4^{\circ} \mathrm{C}$ to remove the insoluble materials. The protein concentrations were determined using a BCA protein assay kit (Pierce). Cytoplasmic and nuclear extracts were prepared with Beyotime Nuclear and Cytoplasmic Extraction Reagents from Beyotime Inc. (Nantong, Jiangsu, China). The procedure was carried out according to the manufacturer's instructions. Forty micrograms of each protein extract was separated using $12 \%$ PAGE, and electro-transferred to polyvinylidene fluoride (PVDF) membranes at $20 \mathrm{~V}$ for $60 \mathrm{~min}$. The membranes were blocked with $5 \%$ skim milk in Tris-buffered saline containing $0.1 \%$ Tween-20. After washing with Tris-buffered saline, the membranes were incubated with the target protein specific antibodies for $14 \mathrm{~h}$ at $4^{\circ} \mathrm{C}$, followed by incubation with horseradish peroxidase-conjugated secondary antibodies for 1 h. Peroxidase activity was visualized using an ECL kit (Bio-Rad) with Chemi Doc XRS ${ }^{+}$(Bio-Rad). For equal loading and normalization purpose, $\beta$-actin was used as internal control.

\section{Statistical Analysis}

Data were analyzed by SPSS 16.0 for Windows (SPSS Inc., Chicago, IL). Statistical analysis was performed with one-way ANOVA with Duncan posttest (unequal variances) to evaluate difference between groups. Each in vitro experiment was repeated at least 3 times, and the data were represented as mean \pm standard deviation. Differences in values were considered significant at $P<0.05$.

\section{RESULTS}

\section{Purification of Anti-Inflammatory Peptides from the WPH}

After $6 \mathrm{~h}$ of hydrolysis with alcalase $2.4 \mathrm{~L}$, WPH were sequentially fractionated through UF membranes with 1- and 5-kDa cut-off values using a tangential flow filtration system. The fractions with MW $<1$ and 1 to $5 \mathrm{kDa}$ showed significant inhibitory activities (Supplemental Figure S2; http://dx.doi.org/10.3168/ jds.2016-11186). Considering the short-chain peptides (dipeptides to heptapeptides, MW $<1 \mathrm{kDa}$ ) that are more easily absorbed in gastrointestinal tract (Grimble, 1994), the fraction below $1 \mathrm{kDa}$ was subjected to size exclusion chromatography on a Sephadex G-25 column and 5 subfractions (F1-F5) were obtained (Supplemental Figure S3A; http://dx.doi.org/10.3168/jds.201611186). Fraction 4 possessed the strongest bioactivities at the final concentration of $100 \mu \mathrm{g} / \mathrm{mL}$ (Supplementary Figures S3B-S3D), and was selected for further preparative HPLC separation. Nine major subfractions (F4a-F4i) were obtained (Figure 1A). All the fractions were collected separately through repeated preparative HPLC chromatograph and used to determine their bioactivities. As shown in Figures 1B-1D, fractions F4c, F4e, and F4i showed significant inhibitory activities on 3 inflammatory mediators at $100 \mu \mathrm{g} / \mathrm{mL}$.

\section{Identification of Peptides with Anti-Inflammatory Potential}

The fractions $\mathrm{F} 4 \mathrm{c}, \mathrm{F} 4 \mathrm{e}$, and $\mathrm{F} 4 \mathrm{i}$ were analyzed by UPLC-Q-TOF-MS to reveal the AA sequences of peptides. For instance, the sequence interpretation of Asp-Tyr-Lys-Lys-Tyr (DYKKY) and Asp-Gln-Trp-Leu (DQWL) was characterized by the accurate elementary composition and $b$ series and $y$ series of fragment ions provided by Q-TOF-MS ${ }^{\mathrm{E}}$ (Figure 2; E indicates elevated). Five $\beta$-LG-derived peptides [Gly-Thr-Trp-Tyr; DYKKY; Leu-Phe; Ala-Val-Phe (AVF); and Trp-TyrSer-Leu] and $3 \alpha$-LA-derived peptides [Trp-Leu-Ala (WLA); DQWL; and Glu-Tyr-Gly-Leu-Phe (EYGLF)] were identified (Table 1). Among them, DYKKY and DQWL are new peptides. In addition, another 3 peptides including AVF, WLA, and EYGLF are reported from the whey protein hydrolysates for the first time. Seven identified peptides contained an aromatic AA (Trp, Tyr, or Phe) at N-terminal or C-terminal, which is consistent with previous reports that alcalase preferred to hydrolyze the peptide bonds containing aromatic AA residues (Doucet et al., 2003).

\section{Effects of the Synthetic Peptides on RAW 264.7 Cell Viability}

To test the potential toxic effects of synthetic peptides on cell, the MTT assay was conducted. The viability of RAW 264.7 cells was not significantly altered by $24 \mathrm{~h}$ of incubation with 10 and $100 \mu \mathrm{g} / \mathrm{mL}$ of synthetic peptides (data not shown). Therefore, the concentrations 

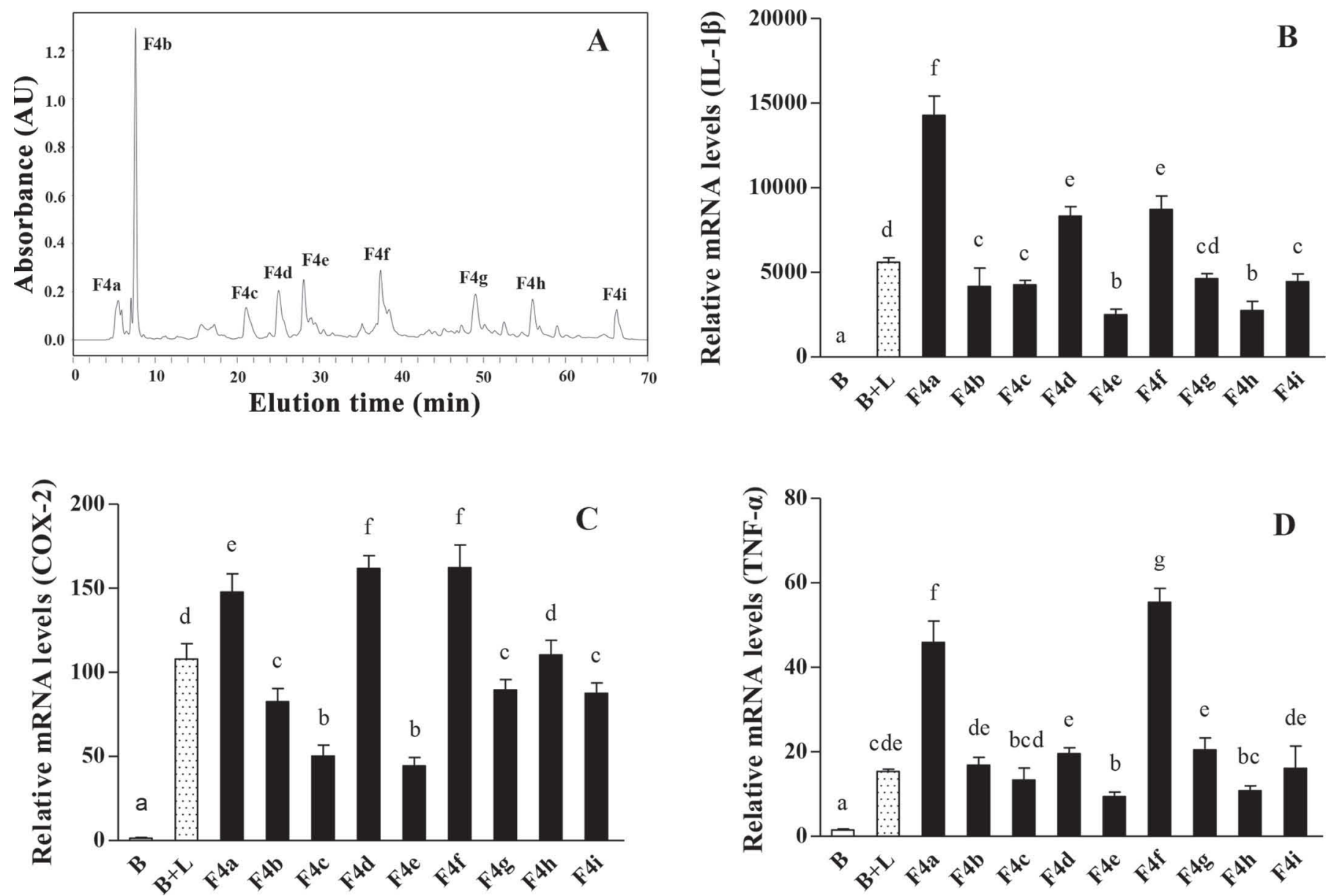

Figure 1. Preparative HPLC chromatogram profile of F4 (A) and the effects of fractions purified by semipreparative HPLC on the expression of IL-1 $\beta$ (B), cyclooxygenase (COX)-2 (C), and tumor necrosis factor (TNF)- $\alpha$ (D) mRNA in the LPS-stimulated mouse RAW 264.7 macrophage cells. The vertical bar represents the SD $(\mathrm{n}=3)$, and different letters $(\mathrm{a}-\mathrm{g})$ represent significant differences $(P<0.05)$.

of 10 and $100 \mu \mathrm{g} / \mathrm{mL}$ for the synthetic peptides were used in subsequent experiments.

\section{Anti-Inflammatory Potential of the Synthetic Peptides on mRNA Expression}

All 8 peptides identified from WPH were synthesized and confirmed their chemical structures by the UPLCQ-TOF-MS method, and evaluated for their inhibitory effects on the mRNA expressions of IL-1 $\beta$, COX-2, and TNF- $\alpha$ in the LPS-stimulated RAW 264.7 mouse macrophages at 10 and $100 \mu \mathrm{g} / \mathrm{mL}$, respectively. As shown in Figure 3, most of synthetic peptides exhibited the concentration-dependent anti-inflammatory potential. Peptide DQWL showed the strongest inhibition on IL$1 \beta$ (49.5 and 59.6\%, respectively) and COX-2 (62.1 and $69.7 \%$, respectively) mRNA expression at both 10 and $100 \mu \mathrm{g} / \mathrm{mL}$; it also reduced TNF- $\alpha$ mRNA expression by 42.9 and $52.4 \%$ at 10 and $100 \mu \mathrm{g} / \mathrm{mL}$ concentra- tions, respectively. In addition, peptide WLA exhibited the strongest suppression on TNF- $\alpha$ mRNA expression $(57.2 \%)$ at $100 \mu \mathrm{g} / \mathrm{mL}$.

\section{Effect of Synthetic Peptides on Production of IL-1 $\beta$ and TNF- $\alpha$ Proteins In Vitro}

To confirm the effects of the synthetic peptides on IL-1 $\beta$ and TNF- $\alpha$ productions, RAW 264.7 macrophage cells were treated with LPS only or LPS and the synthetic peptides at the concentrations of 10 and $100 \mu \mathrm{g} / \mathrm{mL}$. The proinflammatory cytokines content was measured by ELISA. As shown in Figure 4, the protein levels of IL-1 $\beta$ and TNF- $\alpha$ in the LPS-treated cells were attenuated in a concentration-dependent manner compared with the control. The DQWL treatment resulted in 51.3 and $61.5 \%$ reductions for IL- $1 \beta$, and 48.7 and $66.6 \%$ decreases for TNF- $\alpha$ at 10 and 100 $\mu \mathrm{g} / \mathrm{mL}$, respectively. Therefore, DQWL was selected 
Table 1. Peptides identified in fractions F4c, F4e and F4i from whey protein hydrolysate

\begin{tabular}{|c|c|c|c|c|c|}
\hline Fraction & Sequence & $\begin{array}{c}\text { Mass } \\
{\left[(\mathrm{M}+\mathrm{H})^{+}\right]}\end{array}$ & $\begin{array}{c}\text { Calculated } \\
\text { mass }\end{array}$ & $\begin{array}{l}\text { Difference } \\
\quad(\mathrm{ppm})\end{array}$ & Origin \\
\hline $\mathrm{F} 4 \mathrm{c}$ & Gly-Thr-Trp-Tyr (GTWY) & 526.2293 & 526.2302 & -1.7 & $\beta-\mathrm{LG} \mathrm{f}(17-20)$ \\
\hline $\mathrm{F} 4 \mathrm{c}$ & Asp-Tyr-Lys-Lys-Tyr (DYKKY) & 716.3612 & 716.3619 & -1.0 & $\beta$-LG f $(98-102)$ \\
\hline $\mathrm{F} 4 \mathrm{e}$ & Ala-Val-Phe (AVF) & 336.1913 & 336.1923 & -3.0 & $\beta$-LG f $(80-82)$ \\
\hline F4e & Trp-Leu-Ala (WLA) & 389.2185 & 389.2189 & -1.0 & $\alpha-\mathrm{LA} \mathrm{f}(104-106)$ \\
\hline $\mathrm{F} 4 \mathrm{e}$ & Asp-Gln-Trp-Leu (DQWL) & 561.2651 & 561.2673 & -3.9 & $\alpha-$ LA f $(116-119)$ \\
\hline
\end{tabular}

to elucidate the possible pathway behind its potential anti-inflammatory activity.

\section{DQWL Attenuated the Activation of LPS-Induced Signal Pathways}

The effect of DQWL on NF- $\kappa \mathrm{B}$ and mitogen-activated protein kinase (MAPK) signaling pathway was evaluated by Western blot analysis. Lipopolysaccharide stimulation induced a significant increase in inhibitor $\kappa \mathrm{B}$ kinase IKK $\alpha / \beta$ phosphorylation and I $\kappa \mathrm{B} \alpha$ degradation and translocation of cytoplasmic p65 to the nu- cleus, whereas pretreatment with DQWL significantly decreased IKK $\alpha / \beta$ phosphorylation. The level of translocate p65 was also significantly attenuated by DQWL treatment (Figure 5). In addition, DQWL treatment did not affect the expression levels of p38, JNK, and ERK, whereas it significantly decreased the expression level of phosphorylated p38 in the LPS-induced RAW 264.7 macrophages cell. Both JNK and ERK phosphorylations were also inhibited though not at a significant level (Figure 5). These findings suggested that the inhibition of LPS-induced expression of IL-13, COX-2, and TNF- $\alpha$ by DQWL may be dependent on the NF- $\kappa \mathrm{B}$ and p38 MAPK pathway.
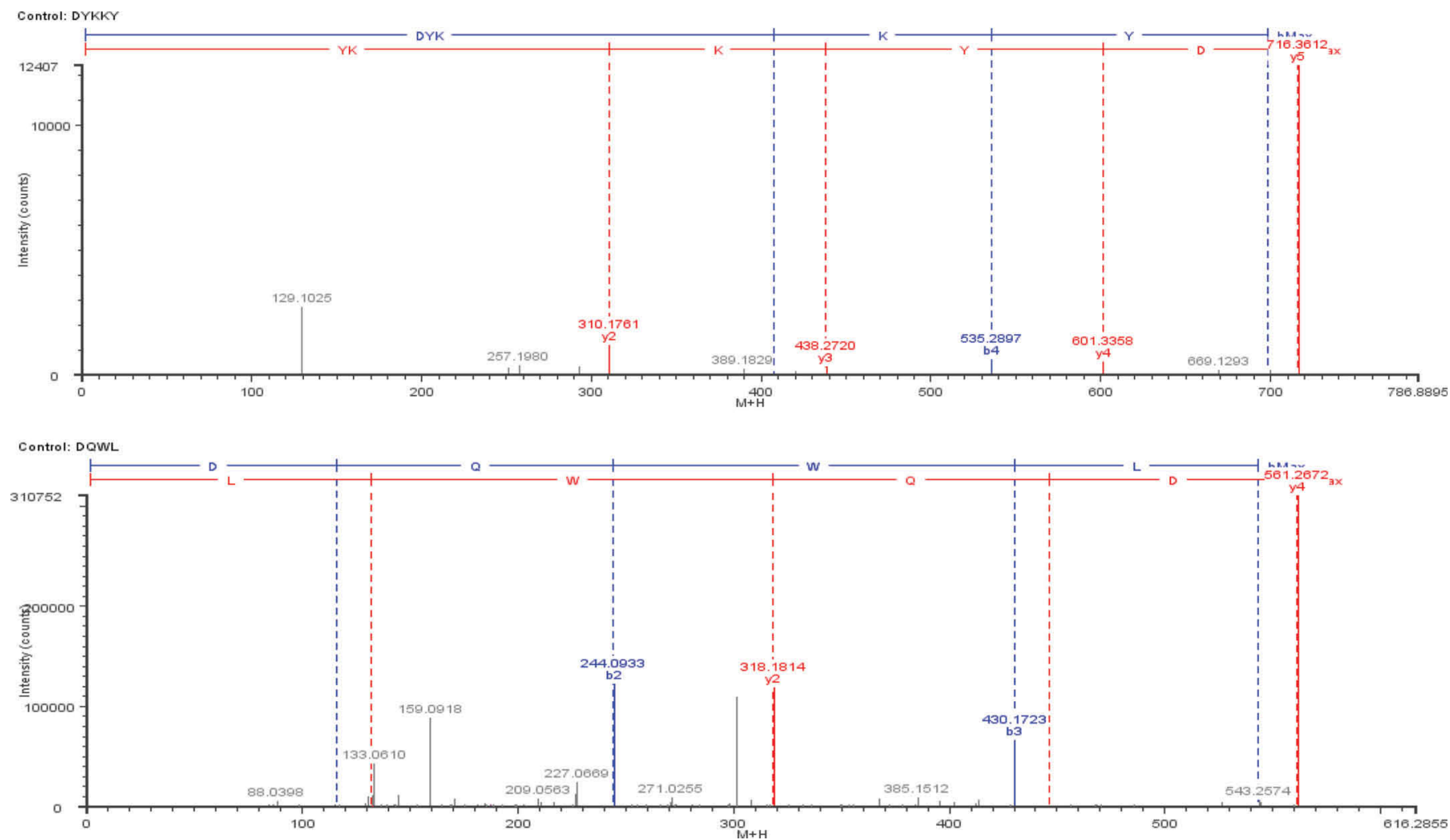

Figure 2. Tandem MS spectra (electrospray ionization, positive mode) of the anti-inflammatory peptides Asp-Tyr-Lys-Lys-Tyr (DYKKY, upper panel) and Asp-Gln-Trp-Leu (DQWL, lower panel). Color version available online. 

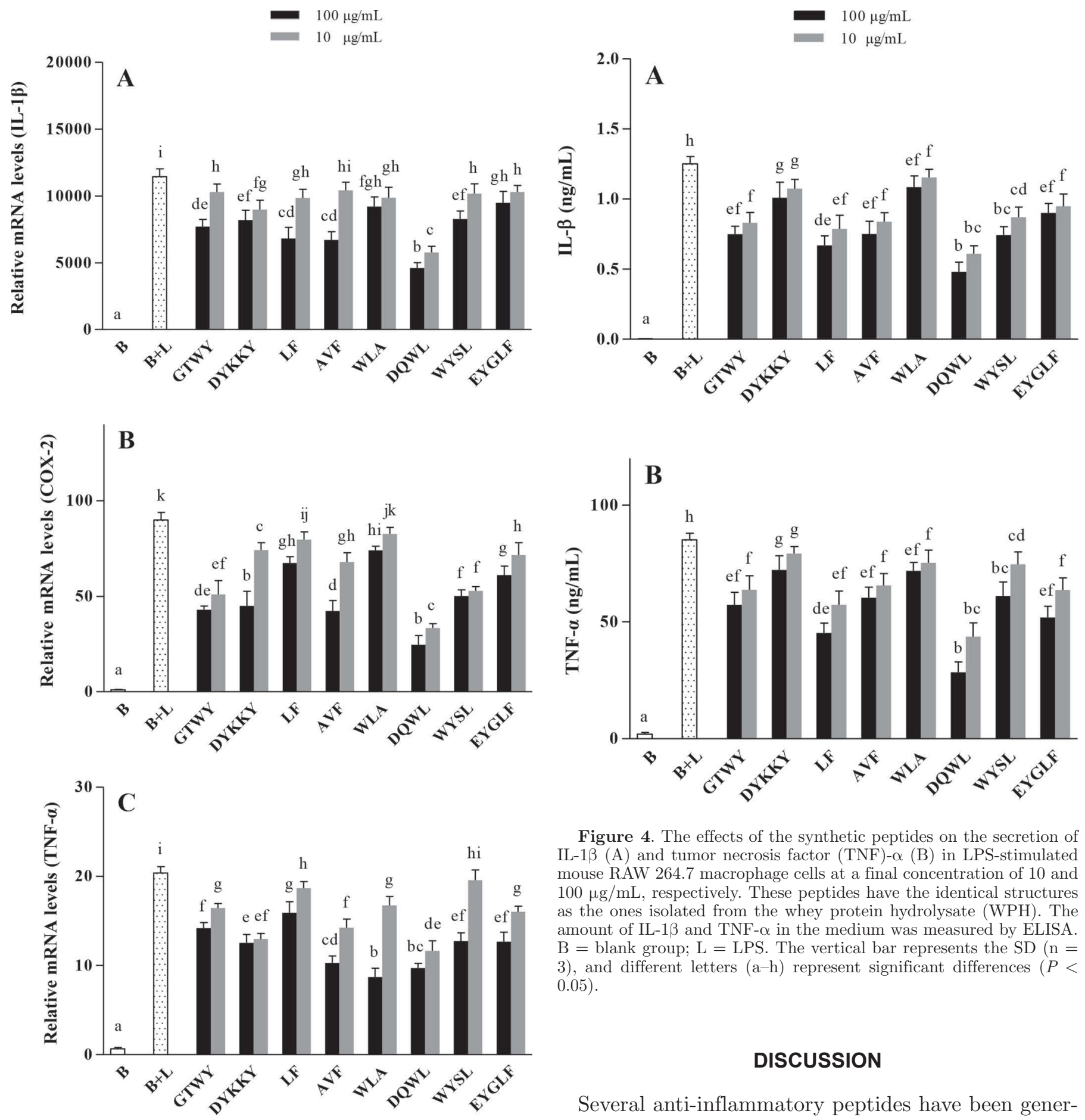

Figure 4. The effects of the synthetic peptides on the secretion of IL-1 $\beta$ (A) and tumor necrosis factor (TNF)- $\alpha$ (B) in LPS-stimulated mouse RAW 264.7 macrophage cells at a final concentration of 10 and $100 \mu \mathrm{g} / \mathrm{mL}$, respectively. These peptides have the identical structures as the ones isolated from the whey protein hydrolysate (WPH). The amount of IL-1 $\beta$ and TNF- $\alpha$ in the medium was measured by ELISA. $\mathrm{B}=$ blank group; $\mathrm{L}=\mathrm{LPS}$. The vertical bar represents the SD $(\mathrm{n}=$ $3)$, and different letters $(\mathrm{a}-\mathrm{h})$ represent significant differences $(P<$ $0.05)$.

Figure 3. The effects of synthesized peptides with on the expression of IL-1 $\beta$ (A), cyclooxygenase (COX)-2 (B), and tumor necrosis factor (TNF)- $\alpha$ (C) mRNA in LPS-stimulated mouse RAW 264.7 macrophage cells at an initial concentration of 10 and $100 \mu \mathrm{g} / \mathrm{mL}$, respectively. These peptides have the identical structures as the ones isolated from the whey protein hydrolysate (WPH). B = blank group; $\mathrm{L}=\mathrm{LPS}$. The vertical bar represents the SD $(\mathrm{n}=3)$, and different letters $(\mathrm{a}-\mathrm{k})$ represent significant differences $(P<0.05)$.

\section{DISCUSSION}

Several anti-inflammatory peptides have been generated by the proteolysis of edible proteins. Majority of the current knowledge on anti-inflammatory peptides has been from cellular studies (Chakrabarti et al., 2014). Two anti-inflammatory peptides, LDAVNR and MMLDF, purified from an edible microalgae, Spirulina maxima, exhibited significant inhibition on the release and production of histamine from antigen-stimulated RBL-2H3 mast cells (Vo et al., 2013). Two tripeptides (IRW and IQW), derived from egg protein, were effec- 
PURIFICATION OF ANTI-INFLAMMATORY WHEY PEPTIDES
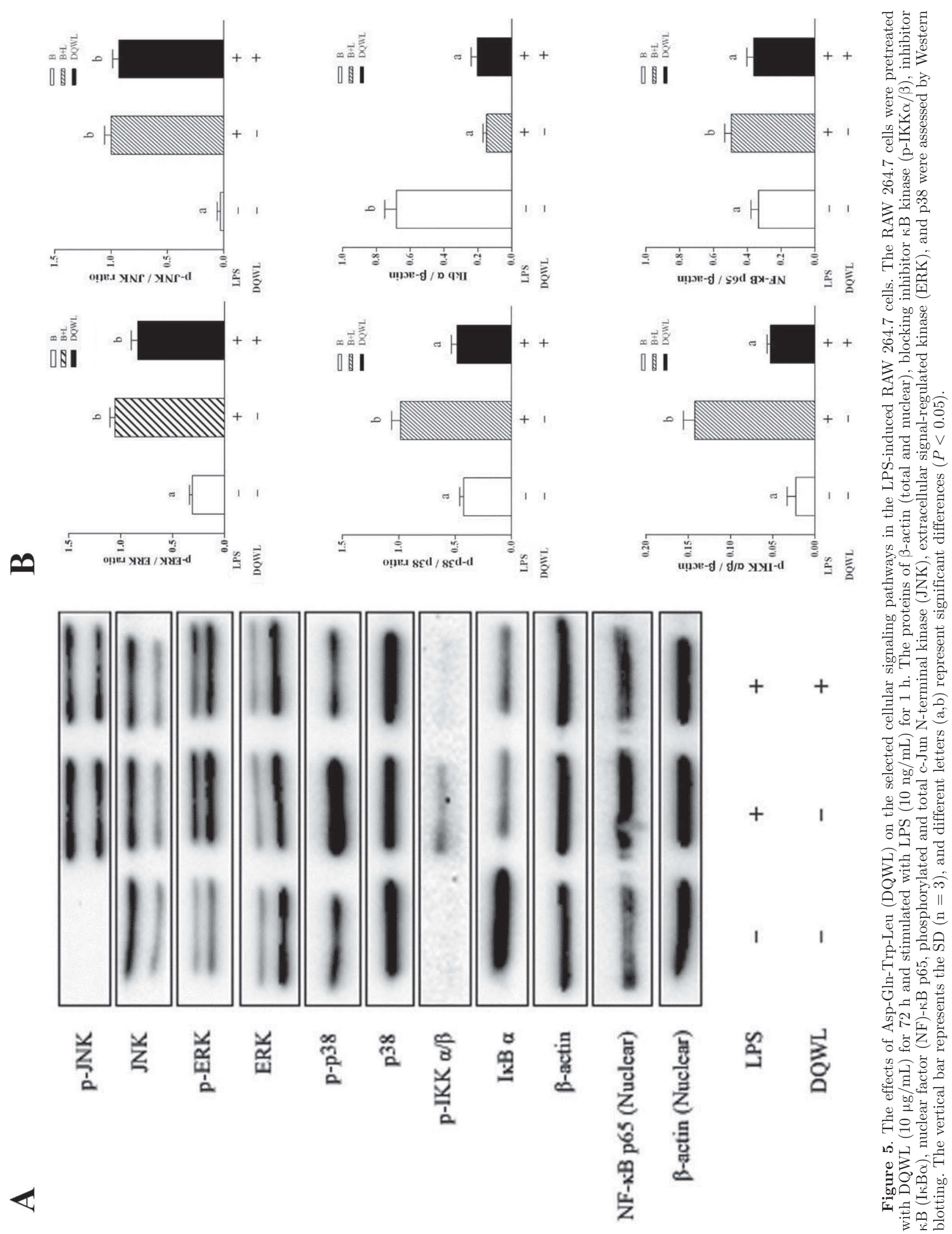
tive in the downregulation of cytokine-induced inflammatory protein expression in vascular endothelium, possibly through the modulation of NF- $\mathrm{B}$ pathway. In recent years, the anti-inflammatory effects of several bioactive peptides and hydrolysates have been evaluated in animal models (Chakrabarti et al., 2014). Two tripeptides, VPP and IPP, demonstrated beneficial effects in a model of intestinal enterocolitis by their mediation of anti-inflammatory activities (Chatterton et al., 2013). Feeding with peptide concentrates obtained from hydrolysis of whey proteins showed significant edema decrease in paw edema test (Mochizuki et al., 2010). Oral intake of a corn gluten hydrolysate reduced inflammatory injury in a rat model of experimental colitis (Tavares et al., 2013). Very recently, a doubleblind clinical study demonstrated the health benefit of collagen peptides on osteoarthritis (Kumar et al., 2015). Increasing evidence suggest that bioactive peptides and edible protein hydrolysates could be a promising alternative anti-inflammation agent because of their high safety.

Although 8 identified peptides in the present study have never been reported to possess anti-inflammatory activities, some of them showed antioxidant or ACEinhibitory activities. The peptide LF obtained after alcalase hydrolysis of whey protein has been described as weak 1,1-diphenyl-2-picrylhydrazyl radical 2,2-diphenyl-1-(2,4,6-trinitrophenyl)hydrazyl and superoxide radical scavengers at a concentration of $500 \mu \mathrm{g} / \mathrm{mL}$ (Zhang et al., 2013); LF was also found in the hydrolysate of salmon muscle by papain, showing $16 \%$ ACEinhibitory activity at a concentration of $50 \mu M$ (Enari et al., 2008). The tripeptide AVF was reported to have an ACE-inhibitory half-maximal inhibitory concentration $\left(\mathrm{IC}_{50}\right)$ value of $2,123 \mu \mathrm{M}$, which was purified from the gastrointestinal hydrolysate of cotton leafworm, Spodoptera littoralis (Vercruysse et al., 2008). The peptide WYSL released from $\beta$-LG was reported to exhibit ACE-inhibitory $\left(\mathrm{IC}_{50}=90.4 \mu M\right)$ and radical scavenging $(4.51 \mu \mathrm{mol}$ of Trolox $/ \mu \mathrm{mol}$ of peptide) capabilities (Hernández-Ledesma et al., 2007).

In the present study, the potential anti-inflammatory effects of purified whey peptides on LPS-induced inflammatory responses were evaluated in RAW 264.7 macrophages. Macrophages can be stimulated and activated by LPS to release a variety of proinflammatory cytokines by binding to the cluster of differentiation 14 /toll-like receptor 4 receptor complex on the cell surface (Netea et al., 2002). Among the proinflammatory cytokines, TNF- $\alpha$ is one of the major inflammatory mediators that involved in many crucial events for the initiation of inflammation (Reimold, 2003). Interleukin$1 \beta$ can initiate signal transduction by activation of NF- $\kappa \mathrm{B}$ and the MAPK during the inflammatory process

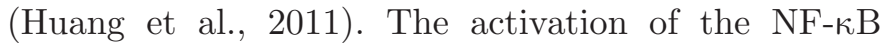
pathway may in turn induce further expression of a series of cytokines, including IL-1 $\beta$ and TNF- $\alpha$, and promote the inflammatory process. Cyclooxygenase- 2 is an inducible enzyme that catalyzes the biosynthesis of prostaglandin $\mathrm{E}_{2}$ and has been proven to play an important role in the development of inflammation (Clària, 2003). Therefore, TNF- $\alpha$, IL-1 $\beta$, and COX-2 were selected as inflammatory markers to investigate the anti-inflammatory potential of WPH and individual purified peptides.

Nuclear factor- $\kappa$ B plays a central role as an inducible transcription factor and is critical for regulation of gene expression in response to inflammation and immunity. The NF- $\kappa \mathrm{B}$ pathway is triggered by LPS and proinflammatory cytokines such as TNF- $\alpha$ and IL-1 $\beta$ (Karin and Ben-Neriah, 2000). The activation of NF- $\kappa B$ leads to the activation of RelA (p65)/p50 complexes. These complexes are regulated by I $\kappa \mathrm{B}$ proteins, which bind $\mathrm{NF}-\kappa \mathrm{B}$, thereby blocking nuclear translocation. When the cells are exposed to proinflammatory stimuli, I $\mathrm{B}$ proteins are phosphorylated by IKK and separated from the NF- $\kappa \mathrm{B}$ complexes. Following activation, NF$\kappa \mathrm{B}$ dimers (p50/p65) translocate to the nucleus and induce the productions of enzymes and cytokines, such as COX-2, inducible nitric oxide synthase (iNOS),

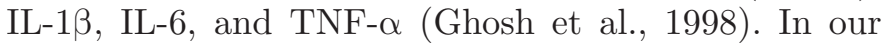
study, determination of NF- $\kappa \mathrm{B}(\mathrm{p} 65), \mathrm{I} \kappa \mathrm{B}$, and phosphorylated IKK $\alpha / \beta$ protein expressions by Western blots showed that DQWL decreased the expression of p65 protein in the nucleus and the phosphorylation of IKK $\alpha / \beta$ (Figure 5); however, DQWL showed no effect on the expression of $\mathrm{I} \kappa \mathrm{B}$.

The MAPK pathway is also responsible for the activation of inflammatory response in LPS-stimulated macrophages (Cargnello and Roux, 2011). The MAPK family is a group of kinases including ERK, JNK, and p38. The activation of ERK and p38 MAP kinase occurs in response to inflammatory stimuli, such as LPS, IL$1 \beta$, and TNF- $\alpha$, and the induction of key inflammatory enzymes, such as COX-2 and iNOS, is attributed to ERK and p38 activation (Dean et al., 1999; CamachoBarquero et al., 2007). Study also indicated that the induction of proinflammatory cytokines is regulated by JNK during the inflammatory processes (Wagner and Nebreda, 2009). In the present study, p38 was involved in the anti-inflammatory potential of DQWL (Figure 5). Taken together, DQWL exerted anti-inflammatory potential via suppressing the expression or production of IL-1 $\beta$, COX-2, and TNF- $\alpha$, which may be regulated by the NF- $\kappa \mathrm{B}$ and MAPK signaling pathways in the LPS-treated RAW 264.7 macrophages. Further studies 
are warranted to establish the signaling pathways responsible for the observed anti-inflammatory potential of DQWL.

Recently, it was shown that the interaction of peptides and LPS may contribute to the anti-inflammatory effects of bioactive peptides (Schmidtchen and Malmsten, 2013, 2015). Peptides may bind to lipid A and prevent a subsequent lipopolysaccharide-binding protein binding, thereby avoiding triggering the cascade leading to NF- $\kappa \mathrm{B}$ activation. Peptides also may induce the LPS scavenging through binding anionic LPS at cell membrane surface to inhibit the toll-like receptor4 binding and $\mathrm{NF}-\kappa \mathrm{B}$ activation. In addition, peptideinduced fragmentation of LPS assemblies may facilitate phagocytosis, resulting in cluster of differentiation 14 binding and suppressing the inflammatory activation. To determine the contribution of the interaction between the peptide and LPS to the anti-inflammatory potential of DQWL, DQWL was either removed before LPS addition to the cells or DQWL and LPS were simultaneously added to the cells after pretreatment following a previously described protocol (Kalle et al., 2014). Compared with the LPS group, the 2 treatment methods significantly $(P<0.05)$ inhibited IL-1 $\beta$, TNF- $\alpha$, and COX-2 mRNA expressions (Supplemental Figures S4A-S4C; http://dx.doi.org/10.3168/jds.201611186). The DQWL treatment before the LPS induction showed similar inhibitory activities on the mRNA expressions of 3 inflammatory mediators as those resulting from simultaneously treatment with LPS and DQWL (Supplemental Figures S4A-S4C), suggesting that the interaction of the bioactive peptide and LPS may contribute little to the anti-inflammatory potential of DQWL. Additional research is required to elucidate the anti-inflammatory mechanisms.

\section{CONCLUSIONS}

Eight peptides with anti-inflammatory potential were obtained from whey protein by alcalase hydrolysates, including 2 new peptides: DYKKY and DQWL. The peptide DQWL showed a significant inhibitory ability on the mRNA expression of IL-1 $\beta, \mathrm{COX}-2$, and TNF- $\alpha$, and the secretion of IL-1 $\beta$ and TNF- $\alpha$ proteins in LPSinduced RAW 264.7 mouse macrophages at concentrations of 10 and $100 \mu \mathrm{g} / \mathrm{mL}$. The inhibitory effects of DQWL on proinflammatory mediators and cytokines were possibly mediated by the inhibition of $N F-\kappa B$ and p38 MAPK signaling pathways.

\section{ACKNOWLEDGMENTS}

This research was supported by the National High Technology Research and Development Program of
China (Grant Nos. 2013AA102202; 2013AA102207; Beijing), a special fund for agro-scientific research in the public interest (No. 201203069; Beijing, China), Shanghai Jiao Tong University 985-III disciplines platform and talent fund (Grant Nos. TS0414115001; TS0320215001; Shanghai, China), Arawana Nutrition and Safety Research Grant (Shanghai, China), a research grant from Wilmar (Shanghai, China) Biotechnology Research \& Development Center Co. Ltd. and a grant from Beijing Advanced Innovation Center for Food Nutrition and Human Health (Beijing, China).

\section{REFERENCES}

Camacho-Barquero, L., I. Villegas, J. M. Sanchez-Calvo, E. Talero, S. Sanchez-Fidalgo, V. Motilva, and C. A. de la Lastra. 2007. Curcumin, a Curcuma longa constituent, acts on MAPK p38 pathway modulating COX-2 and NOS expression in chronic experimental colitis. Int. Immunopharmacol. 7:333-342.

Cargnello, M., and P. P. Roux. 2011. Activation and function of the MAPKs and their substrates, the MAPK-activated protein kinases. Microbiol. Mol. Biol. Rev. 75:50-83.

Carvalho-Silva, L. B., M. T. B. Pacheco, R. Bertoldo, C. Carvalho Veloso, L. C. Teodoro, A. Giusti-Paiva, P. C. B. Lollo, and R. Soncini. 2012. Anti-inflammatory activities of enzymatic (alcalase) hydrolysate of a whey protein concentrate. Afr. J. Biotechnol. 11:2993-2999.

Chakrabarti, S., F. Jahandideh, and J. P. Wu. 2014. Food-derived bioactive peptides on inflammation and oxidative stress. BioMed Res. Int. 2014:608979.

Chatterton, D. E. W., D. N. Nguyen, S. B. Bering, and P. T. Sangild. 2013. Anti-inflammatory mechanisms of bioactive milk proteins in the intestine of newborns. Int. J. Biochem. Cell Biol. 45:1730-1747.

Clària, J. 2003. Cyclooxygenase-2 biology. Curr. Pharm. Des. 9:21772190.

Coussens, L. M., and Z. Werb. 2002. Inflammation and cancer. Nature 420:860-867.

Dandona, P., A. Aljada, A. Chaudhuri, P. Mohanty, and R. Garg. 2005. Metabolic syndrome-A comprehensive perspective based on interactions between obesity, diabetes, and inflammation. Circulation 111:1448-1454.

Dean, J. L. E., M. Brook, A. R. Clark, and J. Saklatvala. 1999. p38 mitogen-activated protein kinase regulates cyclooxygenase-2 mRNA stability and transcription in lipopolysaccharide-treated human monocytes. J. Biol. Chem. 274:264-269.

Doucet, D., D. E. Otter, S. F. Gauthier, and E. A. Foegeding. 2003. Enzyme-induced gelation of extensively hydrolyzed whey proteins by Alcalase: Peptide identification and determination of enzyme specificity. J. Agric. Food Chem. 51:6300-6308.

Dyer, A. R., G. A. Burdock, L. G. Carabin, M. C. Haas, J. Boycec, R. Alsaker, and L. C. Read. 2008. In vitro and in vivo safety studies of a proprietary whey extract. Food Chem. Toxicol. 46:1659-1665.

Enari, H., Y. Takahashi, M. Kawarasaki, M. Tada, and K. Tatsuta. 2008. Identification of angiotensin I-converting enzyme inhibitory peptides derived from salmon muscle and their antihypertensive effect. Fish. Sci. 74:911-920.

Ghosh, S., M. J. May, and E. B. Kopp. 1998. NF-kappa B and rel proteins: Evolutionarily conserved mediators of immune responses. Annu. Rev. Immunol. 16:225-260.

Giugliano, D., A. Ceriello, and K. Esposito. 2006. The effects of diet on inflammation-Emphasis on the metabolic syndrome. J. Am. Coll. Cardiol. 48:677-685.

Grimble, G. K. 1994. The significance of peptides in clinical nutrition. Annu. Rev. Nutr. 14:419-447.

Hernández-Ledesma, B., L. Amigo, I. Recio, and B. Bartolome. 2007. ACE-inhibitory and radical-scavenging activity of peptides derived 
from beta-lactoglobulin $\mathrm{f}(19-25)$. Interactions with ascorbic acid. J. Agric. Food Chem. 55:3392-3397.

Huang, H., Z. H. Cheng, H. M. Shi, W. B. Xin, T. T. Y. Wang, and L. L. Yu. 2011. Isolation and characterization of two flavonoids, engeletin and astilbin, from the leaves of Engelhardia roxburghiana and their potential anti-inflammatory properties. J. Agric. Food Chem. 59:4562-4569.

Kalle, M., P. Papareddy, G. Kasetty, M. J. A. van der Plas, M. Morgelin, M. Malmsten, and A. Schmidtchen. 2014. A peptide of heparin cofactor II inhibits endotoxin-mediated shock and invasive Pseudomonas aeruginosa infection. PLoS ONE 9:e102577.

Kaperonis, E. A., C. D. Liapis, J. D. Kakisis, D. Dimitroulis, and V. G. Papavassiliou. 2006. Inflammation and atherosclerosis. Eur. J. Vasc. Endovasc. Surg. 31:386-393.

Karin, M., and Y. Ben-Neriah. 2000. Phosphorylation meets ubiquitination: The control of NF-kappa B activity. Annu. Rev. Immunol. 18:621-663.

Kumar, S., F. Sugihara, K. Suzuki, N. Inoue, and S. Venkateswarathirukumara. 2015. A double-blind, placebo-controlled, randomised, clinical study on the effectiveness of collagen peptide on osteoarthritis. J. Sci. Food Agric. 95:702-707.

Madureira, A. R., T. Tavares, A. M. P. Gomes, M. E. Pintado, and F. X. Malcata. 2010. Invited review: Physiological properties of bioactive peptides obtained from whey proteins. J. Dairy Sci. 93:437-455.

Mochizuki, M., H. Shigemura, and N. Hasegawa. 2010. Anti-inflammatory effect of enzymatic hydrolysate of corn gluten in an experimental model of colitis. J. Pharm. Pharmacol. 62:389-392.

Netea, M. G., M. van Deuren, B. J. Kullberg, J. M. Cavaillon, and J. W. M. Van der Meer. 2002. Does the shape of lipid A determine the interaction of LPS with Toll-like receptors? Trends Immunol. 23:135-139.

Pan, M. H., C. S. Lai, S. Dushenkov, and C. T. Ho. 2009. Modulation of inflammatory genes by natural dietary bioactive compounds. J. Agric. Food Chem. 57:4467-4477.
Reimold, A. M. 2003. New indications for treatment of chronic inflammation by TNF-alpha blockade. Am. J. Med. Sci. 325:75-92.

Schmidtchen, A., and M. Malmsten. 2013. Peptide interactions with bacterial lipopolysaccharides. Curr. Opin. Colloid Interface Sci $18: 381-392$.

Schmidtchen, A., and M. Malmsten. 2015. (Lipo)polysaccharide interactions of antimicrobial peptides. J. Colloid Interface Sci. 449:136142.

Shahidi, F., and Y. Zhong. 2008. Bioactive peptides. J. AOAC Int 91:914-931.

Sousa, G. T. D., F. S. Lira, J. C. Rosa, E. P. de Oliveira, L. M. Oyama, R. V. Santos, and G. D. Pimentel. 2012. Dietary whey protein lessens several risk factors for metabolic diseases: A review. Lipids Health Dis. 11:67.

Tavares, T. G., H. Spindola, G. Longato, M. E. Pintado, J. E. Carvalho, and F. X. Malcata. 2013. Antinociceptive and anti-inflammatory effects of novel dietary protein hydrolysate produced from whey by proteases of Cynara cardunculus. Int. Dairy J. 32:156-162.

Tuppo, E. E., and H. R. Arias. 2005. The role of inflammation in Alzheimer's disease. Int. J. Biochem. Cell Biol. 37:289-305.

Vercruysse, L., G. Smagghe, T. Matsui, and J. Van Camp. 2008. Purification and identification of an angiotensin I converting enzyme (ACE) inhibitory peptide from the gastrointestinal hydrolysate of the cotton leafworm, Spodoptera littoralis. Process Biochem. 43:900-904.

Vo, T. S., B. Ryu, and S. K. Kim. 2013. Purification of novel antiinflammatory peptides from enzymatic hydrolysate of the edible microalgal Spirulina maxima. J. Funct. Foods 5:1336-1346.

Wagner, E. F. and A. R. Nebreda. 2009. Signal integration by JNK and p38 MAPK pathways in cancer development. Nat. Rev. Cancer 9:537-549.

Zhang, Q. X., H. Wu, Y. F. Ling, and R. R. Lu. 2013. Isolation and identification of antioxidant peptides derived from whey protein enzymatic hydrolysate by consecutive chromatography and QTOF MS. J. Dairy Res. 80:367-373. 